\title{
Research on the application of fuzzy comprehensive evaluation method in civil engineering project procurement
}

\author{
Chunyan Yang ${ }^{1}$, Qiang Liu ${ }^{1 *}$ \\ ${ }^{1}$ College of Harbour and Environmental Engineering, Jimei University, Xiamen 361021, China
}

\begin{abstract}
In order to improve the effectiveness of performance evaluation of civil engineering project procurement, according to the characteristics of civil engineering project procurement management, the procurement performance evaluation method is established based on the fuzzy mathematics theory. Taking a civil engineering project procurement as an example, the implementation effect of the procurement performance evaluation of the civil engineering project is evaluated. The evaluation results are basically consistent with the actual situation, which verifies the effectiveness and reliability of the method. It provides an effective and reference solution for the practical application of procurement performance evaluation in other civil engineering projects.
\end{abstract}

\section{Introduction}

At present, the cost of materials usually accounts for 60 to $70 \%$ of the total cost of construction. Strengthening the management of materials procurement is conducive to reducing costs, improving quality, ensuring the construction period, and increasing the economic benefits of enterprises. Therefore, the internal procurement management of construction enterprises is a very important link, and how to establish an effective, comprehensive and scientific procurement performance evaluation system and method is worth further study.

Foreign scholars have recognized the strategic importance of procurement, and promoted the development of enterprises by strengthening their procurement management. Cox believes that procurement can improve the benefit of the enterprise and the supply chain [1].Pooler proposed 10 specific procurement performance indexes [2].In recent years, domestic scholars' research on the performance evaluation of enterprise procurement has gradually deepened with the development of practice. Huaming Gan believes that the procurement performance evaluation can effectively control the procurement process, facilitate the communication between procurement and other departments, calculate purchasing workload, and facilitate procurement management [3]. Ye Yang proposed that performance evaluation can help enterprises to review their management costs, measure their competitiveness, and reduce procurement costs to increase profits [4]. Based on the Balanced Scorecard theory, Jianhai Feng and Dan Chen introduced the fuzzy analytic hierarchy process to determine the weight of indexes, and carried out non dimensional treatment for each index, and designed a scoring table to evaluate the performance of procurement activities [5].

However, the above research on procurement performance evaluation methods is mainly based on qualitative analysis, and the evaluation technology is relatively backward. There are few researches on purchasing performance evaluation using quantitative analysis method. For this reason, in this paper, a fuzzy comprehensive evaluation method suitable for the material procurement performance of construction enterprises is established based on the theory of fuzzy mathematics. Taking the materials procurement of a civil engineering project as an example, the method is applied to carry out quantitative evaluation, which will provide a more reasonable and reliable method for the procurement performance evaluation of civil engineering projects.

\section{The establishment of civil engineering project procurement performance evaluation model}

Performance evaluation indexes refers to the indexes that can be measured, evaluated and assessed and reflect the performance of the evaluated object according to the relevant business processes within the enterprise [5-8]. According to the characteristics of materials procurement of civil engineering project, the 3 level and 2 stage comprehensive evaluation model is adopted in this paper.

(1) The procurement performance of civil engineering project is regarded as the target level of the evaluation model. The procurement performance of construction enterprises is divided into 4 standard level such as financial, customer, process, learning and growth evaluation indexes.

(2) The standard level selects the relevant evaluation indexes to form the evaluation indexes of the scheme level.

*Corresponding author: liutanq007@aliyun.com 
Among them, the financial evaluation is based on 7 main indexes such as price change rate and proportion of interest expenses. The customer evaluation selects 4 indexes, such as qualified rate and on-time delivery rate. The process evaluation selects 12 main indexes, such as procurement times rate and plan completion rate. The learning and growth evaluation selects 7 indexes, such as procurement organization and management, employee satisfaction.

(3) By constructing the evaluation matrix and determining the weight coefficient vector, the evaluation results of the target, the standard and the scheme level are finally obtained through 2 stages of calculation, to comprehensively evaluate the procurement performance of civil engineering project.

\section{Using AHP to determine the weight of procurement performance evaluation index system}

In the performance evaluation, the weight of each evaluation index directly affects the authenticity and reliability of the evaluation results, and guides the behavior focus and direction of the enterprise managers.

Analytic hierarchy process (AHP) is to construct judgment matrix through pairwise comparison between indexes, and indirectly determines the weight of each index through fuzzy mathematical operation.

\subsection{Comparison and judgment matrix}

In the comprehensive evaluation model of procurement performance, according to the feedback results of the expert questionnaire, the expert score is constructed into a pairwise comparison judgment matrix, and the scale of the judgment matrix is set as shown in Table 1.

Table 1. The scale of judgment matrix and its meaning

\begin{tabular}{|l|l|l|}
\hline Scale $\mathrm{a}_{\mathrm{ij}}$ & Definition & Meaning \\
\hline 1 & $\begin{array}{l}\text { Equally } \\
\text { important }\end{array}$ & $\begin{array}{l}\text { I index is as important as } \mathrm{j} \\
\text { index. }\end{array}$ \\
\hline 3 & $\begin{array}{l}\text { Weak } \\
\text { important }\end{array}$ & $\begin{array}{l}\text { I index is slightly more } \\
\text { important than j index. }\end{array}$ \\
\hline 5 & $\begin{array}{l}\text { Obviously } \\
\text { important }\end{array}$ & $\begin{array}{l}\text { I index is more important than } \mathrm{j} \\
\text { index. }\end{array}$ \\
\hline 7 & $\begin{array}{l}\text { Strongly } \\
\text { important }\end{array}$ & $\begin{array}{l}\text { I index is strongly more } \\
\text { important than j index. }\end{array}$ \\
\hline 9 & $\begin{array}{l}\text { Extremely } \\
\text { important }\end{array}$ & $\begin{array}{l}\text { I index is extremely more } \\
\text { important than j index. }\end{array}$ \\
\hline $\begin{array}{l}\text { Reciprocal } \\
\text { of } \\
1,3,5,7,9\end{array}$ & $\begin{array}{l}\text { Anti } \\
\text { comparison }\end{array}$ & $\begin{array}{l}\text { Compared with i index, the } \\
\text { judgment value of } \mathrm{j} \text { index is } \\
\mathrm{a}_{\mathrm{ij}}=1 / \mathrm{a}_{\mathrm{ji}}\end{array}$ \\
\hline
\end{tabular}

\subsection{Calculation index weight}

First, the judgment matrix is normalized.

$$
\overline{a_{i j}}=\frac{a_{i j}}{\sum_{k=1}^{n} a_{k j}} \quad(i, j=1,2, \ldots \ldots n)
$$

Where, $a_{i j}$ is the judgment value obtained by comparing $\mathrm{i}$ index with $\mathrm{j}$ index.

The normalized judgment matrix is added to the sum vector:

$$
\overline{V_{i}}=\sum_{j=1}^{n} \overline{a_{i j}} \quad(i=1,2, \ldots \ldots n)
$$

The vector $\mathrm{V}$ is normalized to get the feature vector:

$$
W_{i}=\overline{V_{i}} / \sum_{j=1}^{n} \overline{V_{j}} \quad(i=1,2, \ldots \ldots n)
$$

\subsection{Consistency check}

In order to avoid logical judgment error, consistency check should be carried out.

From $\mathrm{AW}=\lambda \max \times \mathrm{W}$, the maximum eigenvalue of matrix $\lambda$ max is obtained:

$$
\lambda_{\max }=\frac{1}{n} \sum \frac{A W_{i}}{W_{i}}
$$

Where, $\mathrm{A}$ is the normalized judgment matrix, and $\mathrm{W}$ is the eigenvector of the index.

Consistency index CI of judgment matrix:

$$
C I=\frac{\lambda_{\max }-\mathrm{n}}{n-1}
$$

Where, $\mathrm{n}$ is the order of the matrix.

The consistency ratio $\mathrm{CR}$ was calculated as follows:

$$
C R=\frac{C I}{R I}
$$

Where, $\mathrm{RI}$ is the average random consistency index.

If $\mathrm{CR}<0.1$, the judgment matrix $\mathrm{A}$ has acceptable satisfactory consistency. In this case, the feature vector W is the weight vector.

\section{Quantitative calculation of procurement performance indexes}

According to the fuzzy evaluation model of procurement performance of construction enterprises, the quantitative evaluation indexes of target, criterion and scheme level can be calculated to comprehensively evaluate the materials procurement performance of construction enterprises. The specific steps are as follows:

(1) Determining the composite weight of evaluation indexes.

Composite weight $=$ criterion layer weight $\times$ scheme layer weight $\times 100$

(2) Dimensionless processing of actual index values. Indexes of different nature should be treated differently [8]. The maximum value of positive index is the optimal value, the minimum value is the worst value, and the reverse index is the opposite. Moderate index has both maximum and minimum, and a moderate value. In the process of dimensionless, we set the maximum value $d_{\max }$ and minimum value $d_{\text {min }}$ for general indexes, and we also need to set an optimal value $\mathrm{d}_{\text {best }}$ for moderate indexes. The actual index value is represented by $\mathrm{d}_{\mathrm{ij}}$, and $\mathrm{Mij}$ is used to represent the dimensionless result. The specific calculation formulas of dimensionless are as follows:

General indexes:

$$
\begin{gathered}
M_{i j}=0, \quad d_{i j} \leq d_{\text {min }} \\
M_{i j}=\frac{d_{i j}-d_{\text {min }}}{d_{\text {max }}-d_{\min }}, d_{\text {min }} \leq d_{i j} \leq d_{\text {max }} \\
M_{i j}=1, \quad d_{i j} \geq d_{\max }
\end{gathered}
$$

Moderate indexes:

$$
\begin{gathered}
M_{i j}=0, \quad d_{i j} \leq d_{\text {min }} \text { or } d_{i j} \geq d_{\text {max }} \\
M_{i j}=\frac{d_{i j}-d_{\text {min }}}{d_{\text {best }}-d_{\text {min }}}, d_{\text {min }}<d_{i j}<d_{\text {best }}
\end{gathered}
$$




$$
\begin{gathered}
M_{i j}=\frac{d_{i j}-d_{\text {best }}}{d_{\text {max }}-d_{\text {best }}}, d_{\text {best }}<d_{i j}<d_{\text {max }} \\
M_{i j}=1, d_{i j}=d_{\text {best }}
\end{gathered}
$$

(3) Calculation of procurement performance indexes score.

Adjust the dimensionless results of the previous step according to the composite weight of the indexes, and calculate the score of each index.

$$
\text { Index score }=M_{i j} \times \text { index composite weight }
$$

(4) Calculation the comprehensive evaluation score of procurement performance.

comprehensive score $=\sum$ Index score

\section{Case analysis}

A construction enterprise has grade I professional qualification such as general contracting of construction engineering and municipal public engineering, and is one of the top 100 enterprises in the province and the first in the city's construction enterprises. Based on the actual situation of the enterprise's civil engineering project procurement management in 2020, and according to the weight questionnaire survey of the expert group composed of the senior management of the construction enterprises, the head of the procurement department with senior titles, the head of the financial department and other experts, the importance of each evaluation index at all levels is assigned. A comprehensive evaluation model is finally established to carry out the materials procurement performance of civil engineering projects in 2020 to verify the effectiveness of the model.

According to the calculation method of the third section, the weights and composite weights of the indexes of the standard and the scheme layer are obtained, and the specific weights are shown in Table 2. According to the calculation method in the fourth section, the scores of various indexes and comprehensive evaluation scores of the procurement performance evaluation of civil

\begin{tabular}{|c|c|c|c|c|}
\hline \multicolumn{2}{|c|}{ Procurement performance index } & \multirow[b]{2}{*}{ 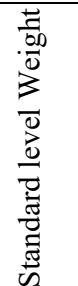 } & \multirow[b]{2}{*}{ 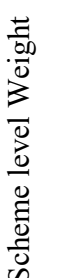 } & \multirow[b]{2}{*}{ 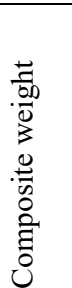 } \\
\hline 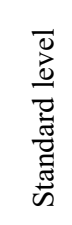 & Scheme level & & & \\
\hline \multirow{7}{*}{ 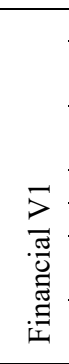 } & Price change rate V11 & \multirow[t]{7}{*}{0.25} & 0.36 & 9.00 \\
\hline & $\begin{array}{l}\text { Proportion of interest } \\
\text { expense V12 }\end{array}$ & & 0.26 & 6.50 \\
\hline & $\begin{array}{l}\text { Average payment period } \\
\text { V13 }\end{array}$ & & 0.14 & 3.50 \\
\hline & Inventory loss rate V14 & & 0.07 & 1.75 \\
\hline & Inventory turnover days V15 & & 0.07 & 1.75 \\
\hline & $\begin{array}{l}\text { Procurement management } \\
\text { expenses ratio V16 }\end{array}$ & & 0.08 & 2.00 \\
\hline & $\begin{array}{l}\text { Business promotion } \\
\text { expenses ratio V17 }\end{array}$ & & 0.02 & 0.50 \\
\hline \multicolumn{4}{|c|}{ Subtotal } & 25 \\
\hline
\end{tabular}
engineering projects are obtained, as shown in Table 3.

\begin{tabular}{|c|c|c|c|c|}
\hline \multirow{4}{*}{ 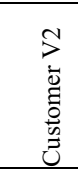 } & Qualified rate V21 & \multirow[t]{4}{*}{0.25} & 0.39 & 9.75 \\
\hline & On-time delivery rate V22 & & 0.22 & 5.50 \\
\hline & Quantity accuracy rate V23 & & 0.10 & 2.50 \\
\hline & Customer satisfaction V24 & & 0.29 & 7.25 \\
\hline \multicolumn{4}{|c|}{ Subtotal } & 25 \\
\hline \multirow{12}{*}{ 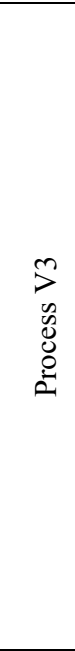 } & $\begin{array}{l}\text { Order information accuracy } \\
\text { rate V31 }\end{array}$ & \multirow[t]{12}{*}{0.32} & 0.08 & 2.56 \\
\hline & Procurement time rate V32 & & 0.08 & 2.56 \\
\hline & Plan completion rate V33 & & 0.23 & 7.36 \\
\hline & $\begin{array}{l}\text { Safety stock reduction rate } \\
\text { V34 }\end{array}$ & & 0.18 & 5.76 \\
\hline & Stockout frequency V35 & & 0.13 & 4.16 \\
\hline & $\begin{array}{l}\text { Proportion of e-procurement } \\
\text { V36 }\end{array}$ & & 0.07 & 2.24 \\
\hline & $\begin{array}{l}\text { Invoice receipt days out of } \\
\text { date V37 }\end{array}$ & & 0.02 & 0.64 \\
\hline & Flexible procurement V38 & & 0.05 & 1.60 \\
\hline & $\begin{array}{l}\text { Information sharing level } \\
\text { V39 }\end{array}$ & & 0.04 & 1.28 \\
\hline & $\begin{array}{l}\text { Proportion of suppliers } \\
\text { involved in process } \\
\text { optimization V310 }\end{array}$ & & 0.06 & 1.92 \\
\hline & Supplier collaboration V311 & & 0.03 & 0.96 \\
\hline & $\begin{array}{l}\text { Flow ratio of large and medium- } \\
\text { sized suppliers V312 }\end{array}$ & & 0.03 & 0.96 \\
\hline \multicolumn{4}{|c|}{ Subtotal } & 32 \\
\hline \multirow{7}{*}{ 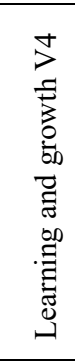 } & $\begin{array}{l}\text { Procurement organization } \\
\text { and management V41 }\end{array}$ & \multirow[t]{7}{*}{0.18} & 0.27 & 4.86 \\
\hline & $\begin{array}{l}\text { Business communication } \\
\text { frequency V42 }\end{array}$ & & 0.16 & 2.88 \\
\hline & ERP Implementation V43 & & 0.05 & 0.90 \\
\hline & $\begin{array}{l}\text { Growth rate of amount } \\
\text { completed per capita V44 }\end{array}$ & & 0.26 & 4.68 \\
\hline & $\begin{array}{l}\text { Growth rate of orders } \\
\text { completed per capita V45 }\end{array}$ & & 0.10 & 1.80 \\
\hline & Employee satisfaction V46 & & 0.10 & 1.80 \\
\hline & Staff training times V47 & & 0.06 & 1.08 \\
\hline \multirow{2}{*}{\multicolumn{4}{|c|}{$\begin{array}{l}\text { Subtotal } \\
\text { Total Sce }\end{array}$}} & 18 \\
\hline & & & & 100 \\
\hline
\end{tabular}

Table 2. Weights of indexes for procurement performance
The implementation of the enterprise's civil engineering project procurement performance in 2020 can be comprehensively evaluated from Table 3 . As can be seen from table 3 , the comprehensive score of the civil engineering project procurement performance is 78.77 . Among them, the financial subtotal score is 15.11 , the customer subtotal score is 22.08 , the process subtotal score is 25.89 , and the learning and growth subtotal score is 15.69. Compared with the standard score, the compliance rate was $60.44,88.32,80.90$ and $87.16 \%$. Each evaluation index reflects the actual situation of the company. The above quantitative evaluation indexes are due to the severe impact of COVID-19 epidemic in 2020, which causes the price of purchased materials of the civil engineering project to rise and the proportion of interest expenditure to be large, so the score of financial evaluation

\begin{tabular}{|c|c|c|c|c|c|c|c|}
\hline \multicolumn{2}{|c|}{$\begin{array}{l}\text { Procurement } \\
\text { performance } \\
\text { index }\end{array}$} & \multicolumn{3}{|c|}{ Grading } & \multirow[b]{2}{*}{ 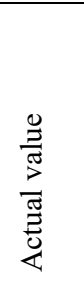 } & \multirow[b]{2}{*}{$\mathrm{M}_{\mathrm{ij}}$} & \multirow[b]{2}{*}{ 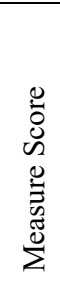 } \\
\hline 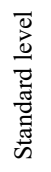 & 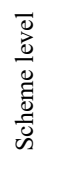 & 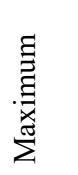 & $\stackrel{\Xi}{\Xi}$ & 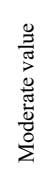 & & & \\
\hline \multirow[t]{2}{*}{ V1 } & V11 & $2 \%$ & $10 \%$ & & $6 \%$ & 0.50 & 4.5 \\
\hline & V12 & $0.80 \%$ & $4.10 \%$ & & $2.30 \%$ & 0.55 & 3.58 \\
\hline
\end{tabular}
indexes were relatively low.

Table 3.Assessment scoring table for procurement performance 


\begin{tabular}{|c|c|c|c|c|c|c|c|}
\hline & V13 & 60 & 28 & & 52 & 0.75 & 2.63 \\
\hline & V14 & $0.90 \%$ & $1.50 \%$ & & $1 \%$ & 0.77 & 1.35 \\
\hline & V15 & 20 & 63 & & 36 & 0.63 & 1.10 \\
\hline & V16 & $0.20 \%$ & $0.80 \%$ & & $0.31 \%$ & 0.82 & 1.64 \\
\hline & V17 & $1.07 \%$ & $0.86 \%$ & $1 \%$ & $0.95 \%$ & 0.64 & 0.32 \\
\hline Sul & & & & & & & 15.11 \\
\hline V2 & V21 & $98 \%$ & $92 \%$ & & $97.5 \%$ & 0.92 & 8.97 \\
\hline & V22 & $99 \%$ & $93 \%$ & & $98.5 \%$ & 0.92 & 5.06 \\
\hline & V23 & $97.2 \%$ & $92 \%$ & & $96.7 \%$ & 0.90 & 2.25 \\
\hline & V24 & 95 & 85 & & 93 & 0.80 & \begin{tabular}{|l|l|}
5.8 \\
\end{tabular} \\
\hline Sul & & & & & & & 22.08 \\
\hline V3 & V31 & $100 \%$ & $99 \%$ & & $99.8 \%$ & 0.80 & 2.05 \\
\hline & V32 & $100 \%$ & $97 \%$ & & $99.8 \%$ & 0.93 & 2.38 \\
\hline & V33 & $100 \%$ & $97 \%$ & & $99.7 \%$ & 0.90 & 6.62 \\
\hline & V34 & $12 \%$ & 0 & & $7 \%$ & 0.58 & 3.34 \\
\hline & V35 & 0 & 10 & & 2 & 0.80 & 3.33 \\
\hline & V36 & $99.5 \%$ & $95 \%$ & & $99 \%$ & 0.90 & 2.02 \\
\hline & V37 & 0 & 30 & & 10 & 0.67 & 0.43 \\
\hline & V38 & 1.05 & 0.92 & 1 & 0.98 & 0.75 & 1.20 \\
\hline & V39 & 5 & 1 & & 5 & 1.00 & 1.28 \\
\hline & V310 & $90 \%$ & $70 \%$ & & $85 \%$ & 0.75 & 1.44 \\
\hline & V311 & $10 \%$ & $2 \%$ & $3 \%$ & $3.0 \%$ & 1.00 & 0.96 \\
\hline & V312 & 5 & 1 & & 4.5 & 0.88 & 0.84 \\
\hline Sul & & & & & & & 25.89 \\
\hline & V41 & 5 & 2 & & 4.2 & 0.73 & 3.55 \\
\hline V4 & V42 & 12 & 8 & & 12 & 1.00 & 2.88 \\
\hline & V43 & 5 & 1 & & 4 & 0.75 & 0.68 \\
\hline & V44 & $16 \%$ & 0 & & $16 \%$ & 1.00 & 4.68 \\
\hline & V45 & $15 \%$ & 0 & & $13 \%$ & 0.87 & 1.57 \\
\hline & V46 & 5.00 & 1.00 & & 3.80 & 0.70 & 1.26 \\
\hline & V47 & 5 & 0 & 3 & 3 & 1.00 & 1.08 \\
\hline Sul & & & & & & & 15.69 \\
\hline Tot & score & & & & & & 78.77 \\
\hline
\end{tabular}

In addition, due to the enterprise strengthens the internal procurement management, pays more attention to customer evaluation, has high qualified rate and on-time delivery rate, pays attention to the growth and development of employees, has high level of information sharing, and cites the supply chain and other advanced management concept and methods, so the customer, process, learning and development evaluation index score are relatively high.

In summary, it is suggested that the enterprise should further optimize the management of the procurement process and focus on the financial evaluation indexes in the materials procurement management of civil engineering projects in the future.

\section{Conclusion}

(1) According to the characteristics of civil engineering project procurement, a performance evaluation model of civil engineering project material procurement is established based on the theory of fuzzy mathematics, and the specific evaluation method of this model is given.

(2) Taking the material procurement of a civil engineering project as an example, the evaluation model is applied to the comprehensive evaluation of procurement performance. The evaluation results are basically consistent with the actual situation, which verifies the correctness and reliability of the model.

(3) The evaluation method can be used to calculate various indexes of the procurement performance evaluation of civil engineering project, thus providing a decision-making basis for the procurement management in other civil engineering projects.

\section{References}

1. Cox A. Relational competence and strategic procurement management: towards an entrepreneurial an contractual theory of the firm. European Journal of Purchasing and Supply Management, 1996(01): 57-70.

2. Pooler VH. Measuring the purchasing man: trend. Journal of Purchasing, 1973, 40(11): 68-85.

3. Gan Huaming, Xie Xinyan. Rapid procurement management. Beijing: Enterprise Management Publishing House, 2003(05): 193-217.

4. Yang Ye. Formulate the performance evaluation system of enterprise procurement. Population \& Economics, 2006(01): 80-82.

5. Feng Jianhai, Chen Dan. Procurement Performance Evaluation of Enterprise Based on BSC. Finance and Accounting Monthly, 2011(09): 26-28.

6. Wang Zhihua. Discussion on performance evaluation index of railway construction project material procurement in the new period. Railway Purchasing and Logistics, 2019(01): 47-49.

7. Wang Lian. Enterprise procurement performance evaluation system under ERP environment. Finance and Accounting Monthly, 2006(05) : 64-65.

8. Sun YanBing. Application of BSC in Performance Management of High-tech Enterprises, Finance and Accounting Monthly, 2019(01): 33-39. 